Poznań

\title{
Poland towards the migration crisis of $2015-2016^{1}$
}

\begin{abstract}
The migratory pressures brought to bear on the European Union member states since the early 2015 have deepened differences of approach to addressing the migration crisis, especially as regards the quota system adopted in September 2015. The paper presents Poland's position on the escalating crisis, its arguments for abandoning the open door policy on immigration as well as the political and legal measures undertaken by Poland.
\end{abstract}

Key words: migration crisis, refugees, European Union, Poland, relocation

$\mathbf{T}$ riggered initially by the developments of the Arab Spring, escalated through the Syrian conflict and felt mainly in European Union member states, the migrant crisis prompted legal and political measures aimed, on the one hand, at extending protection to persons in need and, on the other, at safeguarding the security of the EU member states and their citizens. In the early years of the crisis, the European Union and its individual member states declared their commitment to welcoming persons who were fleeing their home countries out of fear of persecution and the adverse consequences of the ongoing conflicts. Their initial reaction stands in stark contrast to the tone of the current debate on the future of the EU immigration and asylum policies, which is dominated by calls for curbing the influx of foreigners and sealing external borders. This change of heart has resulted primarily from a rise in incoming migration streams, controversies regarding the nature of migration flows and the fear of Islamization fueled by certain European politicians.

The term "migration crisis" used in the title of this paper reflects the nature of the phenomenon which has been observed since the end of 2014. While the initial arrivals in the European Union being the consequences of the Arab Spring were predominantly characterized by people in need of international protection, things changed as of the late 2014 as the majority of the immigrants to the European Union have since been economic migrants. For that reason, the terms "immigrant" and "migrant", as used herein, refer to any person arriving in the European Union from a third country whereas the term "refugee" is used exclusively to denote such persons as characterized in Art. 1A of the Geneva Convention of 1951 relating to the Status of Refugees, following the 1967 modifications made in accordance with the New York Additional Protocol. ${ }^{2}$

1 This text was completed on May 16, 2016.

2 "For the purposes of the present Convention, the term "refugee" shall apply to any person who $[\ldots]$ owing to well-founded fear of being persecuted for reasons of race, religion, nationality, membership of a particular social group or political opinion, is outside the country of his nationality and is unable or, owing to such fear, is unwilling to avail himself of the protection of that country; or who, not having a nationality and being outside the country of his former habitual residence as a result of such events, is unable or, owing to such fear, is unwilling to return to it" (Convention, 1951, Art. 1A). 
The text embarks on outlining and assessing Poland's position on the migration crisis, as displayed in 2015 and the early 2016. Its discussion focuses on reviewing the stance of two governments (Ewa Kopacz and Beata Szydło administrations) adopted not only in the process of collaboration with other EU member states but also in response to pressures from Polish political opposition parties and the public opinion. The examination of the debate which commenced in 2015 is intended to show discrepancies between Poland's commitments under international law - arising in part from the Convention relating to the Status of Refugees - and the effort to protect the state territory and its citizens from an influx of foreign nationals from the Middle East and Africa. Before proceeding to the main strand of the analysis, the review of the Polish Presidency activities aimed at handling the migration crisis during its initial phase of 2011 will be presented, as a way to depict a change of approach to the issue in question.

\section{Migration crisis as a challenge for the Polish Presidency}

Migration pressure observed in the EU member states came in the wake of the migration flows precipitated by the Arab Spring. Since 2011, migrants traveled to the European Union via Malta and Italy. According to UNHCR, ca. 88,500 people fled from Northern Africa between February 20 and March 2, 2011, with as many as 85,000 originating in Tunisia (Update No. 1, 2011). Since these early beginnings, unorganized migration flows could be observed heading for the European Union, in particular, for Italy. From mid-January to March 14, 2011, over 8,800 migrants arrived in the tiny Italian seaport of Lampedusa located roughly $225 \mathrm{~km}$ off the coast of Tunisia and some $280 \mathrm{~km}$ from Sicily. By mid-April 2011, the Maltese authorities reported the arrival of over a thousand migrants. By mid-May 2011, nearly 38,000 migrants made it to Italy, a vast majority of them originating in Tunisia (ca. 24,000) and Libya (ca. 14,000). By mid-June, the figures rose to 43,000 (Update No. 26, 2011), 1,500 of whom ended up in Malta while all others went to Italy.

In response to the North African crisis, the European Union appropriated additional funds to assist persons in need. Actions were also taken to better secure the Mediterranean member states. Commenced in February 2011 at Italy's request, Joint Operation Hermes, carried out by the European Agency for the Management of Operational Cooperation at the External Borders of the Member States of the European Union - Frontex with the involvement of twelve member states and Switzerland (relying on Europe's rapid border intervention teams), was to help resolve the situation involving migrants, refugees and persons in a refugee-like situation. The idea was to extend assistance in guarding the southern border of the EU and checking boats carrying migrants headed for the territorial sea waters of Italy. In addition to humanitarian relief and measures aimed at restoring security along internal borders, debates were held on reforming the common immigration and asylum policies. Regular meetings were also arranged to find ways to secure the member states and stem the flow of migrants who did not require protection. ${ }^{3}$ A need was noted to step up cooperation with countries of origin and support democratic

${ }^{3}$ This concerned predominantly economic migrants from Algeria, Egypt, Morocco, Tunisia as well as Eritrea and Somalia. More: Annual Risk Analysis 2013, p. 30-31. 
tendencies in such countries. Such measures were hoped to bring about internal stability, thought of as the best way to check migration pressure. However, the key objective was to persuade the member states to provide technical and personal assistance in managing migration flows from North Africa.

The first stage of the migrant crisis coincided with the Polish presidency in the Council of the European Union held from July 1 to December 31, 2011. As intended by the Polish authorities, the presidency was to help achieve the objectives of Polish foreign policy. After all, although the presidency's agenda is expected to cater to the interests of the entire European Union and all of its member states, there are always practical ways of inserting individual intentions and masking one's own interests (Czachór, 2011, p. 27). As a consequence, in setting out on the drafting of the agenda, the government enumerated preliminary criteria that were essential for selecting priorities. Those included the internal and external challenges and needs faced by the EU; the international and internal situation; the common interests and goals of the states involved in the presidency Troika and the specific interests of Poland (Polish Presidency, 2011, p. 15).

While the agenda of the Polish presidency had been prepared long before the presidency actually began, the revolutionary developments in North Africa affected it considerably. Therefore Poland was forced to reassess the central aim of its foreign policy, which was to assumed the role of "a patron and promoter of the Eastern policy" of the European Union. Poland could not ignore the dramatic and rapid social and political changes (seen initially as the commencement of democratization) in the immediate vicinity of the European Union and focus exclusively on the eastern dimension of the Common Security and Defense Policy (CSDP). On the one hand, the developments in North Africa drew the attention of the member states away from issues considered to be essential by the Polish presidency focusing it on the EU's southern neighborhood. Nevertheless, the developments gave Poland a unique opportunity to launch a debate on reforming the neighborhood policy and promote the idea of establishing the European Endowment for Democracy. Poland's response to the events unfolding in North Africa was neither swift nor radical. Rather than adopting ad hoc measures, Poland expressed an intent to "promote comprehensive solutions applicable to the entire European Union and its environment by, among others, striking a balance between the southern and northern dimensions" of the CSDP (Jankowski, 2011, p. 61).

\section{Poland's response to the crisis proceeded in two directions}

One of them was an effort to support democratization in North African and Middle Eastern countries on the premise that success in stemming the flow of migrants - citizens of those states hinged on eliminating the root causes of involuntary migration. In reference to the events in Egypt, Libya, Tunisia and the other states of the so-called Southern Neighborhood, the "cooperation based on partnership, focused on supporting democratic transformations, building modern state structures underpinned by constitutional reforms, enhancing the judicial system and security and fighting corruption" was proposed, as well as EU support in the area of "the protection of fundamental freedoms" in order to prevent minorities persecution (Polish Presidency, 2011: 10). Success in democratizing 
such states was also associated with economic growth. To that end, closer trade relations needed to be forged. Therefore, the Polish presidency favored a democratization through stability. It sought to become a 'democracy expert' capable of extending assistance in the launching of democratic reforms and was willing to provide it (see: Jańczak, 2011, p. 144). The success of Poland's transition was quoted during official parliamentary visits (e.g. in Tunisia in March 2011), ministerial visits (such as those of the Minister of Foreign Affairs to Egypt, Libya and Tunisia in 2011) as well as study visits attended by North African delegates (such as the conference marking the $30^{\text {th }}$ anniversary of the first Solidarity convention attended by the new representatives of Tunisia and Egypt). Attempts were also made to put political pressure on the states involved in the Arab Spring and call on them to uphold democratic values and principles and honor international commitments regarding the protection of human rights (as in the case of an appeal to Syrian authorities made in August 2011). Poland tangibly contributed to fostering democracy in the states undergoing democratization in the wake of the Arab Spring by helping set up the European Endowment for Democracy. This new financial instrument supporting transitions in EU neighboring countries by means of funding NGO projects and social initiatives, was approved by the member states.

The other direction of the activities undertaken by the Polish presidency in the face of the growing migrant crisis was to insist firmly on blocking the efforts of certain member states to depart from the Schengen regime. The massive influx of migrants from the countries of North Africa was seen as a security risk and a factor for destabilizing the EU internal situation. As a consequence, the authorities of Italy, France and Germany opted for amending the Schengen agreements to allow for the adoption of internal border checks. With the support of e.g. Belgium, the Polish presidency noted that such ideas were in stark contrast to the principle of a "Europe without frontiers", contradicting European integration and undermining the significance of the freedoms that underpin the operation of the EU, especially the free movement of persons. During an informal meeting of the ministers of justice and internal affairs of the member states (held in Sopot on July 18-19, 2011) aimed at discussions on the functioning of the Schengen area and the Common European Asylum System as well as options for increasing the efficiency of external border management (Nieformalna, 2011), Poland proposed to disseminate "best practices in border protection" (Polish Presidency, 2011, p. 8). It postulated that measures be taken to streamline border management in the Schengen area and that new immigration and asylum policy instruments be enacted to open up a way for legalizing immigration and creating "an effective sustainable return and readmission policy" (Ibid., p. 25). In Poland's opinion, "[t]he stability of Schengen has been challenged by uncoordinated and unilateral efforts to tackle collective problems [...]. A departure from Schengen rules would have negative effects on the European economy [...]. It would also lower the level of security now enjoyed by European citizens" (Nieformalna, 2011, p. 1).

The role of the presidency was to keep the Schengen regime intact. To that end, Poland proposed to strengthen operational cooperation on the European Union's external borders to ensure the security and protection of public order within the Union. In particular, the official postulates of the Polish presidency concerned extending the competences of Frontex, strengthening cooperation with third countries in the area of border protection 
and combating cross-border crime and irregular migration flows. Such ideas were deliberated during a conference in Poznań in November 2011, which resulted in the adoption of the Action Plan of the Prague Process - Building Migration Partnerships 2012-2016. Other outcomes included the successful adoption of a new regulation on Frontex in October 2011 and of the so-called Qualification Directive in December 2011.

The former was to strengthen the Agency's operational capacities and, in particular, establish special border guard teams assigned to joint operations and pilot projects. It confirmed that: „one or more Member States facing specific and disproportionate pressures, and confronted with circumstances requiring increased technical and operational assistance [...] with regard to control and surveillance of external borders may request the Agency for assistance” (Regulation No. 1168/2011, 2011, Art. 8.1). And ,at the request of a Member State faced with a situation of urgent and exceptional pressure $[\ldots]$ of large numbers of third-country nationals trying to enter the territory of that Member State illegally", the Agency may send one or more European Border Guard Teams (Regulation No. 1168/2011, 2011, Art. 8a).

The Qualification Directive, in its turn, defined standards for extending international protection, refugee status or subsidiary protection to third country nationals and stateless persons. The adoption of unified qualification criteria and the approximation of asylum rules was to help limit the so-called secondary movements and multiple applications for protection by the same individuals. The Directive required applicants "to submit as soon as possible all elements needed to substantiate the application for international protection" (Directive, 2011, Art. 4.1). A provision was introduced that the actors of such persecution as justifies an application for protection in the European Union may be states, parties or organizations controlling the State or "a substantial part" of the territory of a State, as well as non-State actors. However, persecution by the latter can only be recognized as grounds for providing protection in the $\mathrm{EU}$ if it is possible to demonstrate that state actors "are unable or unwilling to provide protection against persecution or serious harm" (Directive, 2011, Art. 6c). Although beneficial for the member states, such solutions have been criticized by the UNHCR, the International Committee of the Red Cross and non-governmental organizations dealing with asylum matters. Even as early as the consultations stage, inconsistencies with international provisions were raised. Other than the above, reference was made to the controversial provision barring EU protection if in a part of a state of origin there is "no well-founded fear of being persecuted" or no real risk of suffering serious harm (Directive, 2011, Art. 8a). Effectively, the member states are suggesting that an applicant was able to obtain protection in (another part of) his/her own country and should thus seek the status of an internally displaced person. However, such a solution runs counter to the freedom of applying for refugee status enshrined in the Convention relating to the Status of Refugees of 1951.

\section{Two governments - two positions}

As the Syrian conflict escalated in the following years, and given the permanent presence of European rapid border intervention teams (RABITs) in the Mediterranean, growing migration pressure was observed from Turkey. In total in 2015, the European 
Union received more than 1.2 million migrants, roughly 154,000 of whom (coming in part from Eritrea and Nigeria) reached the Union via the so called western and central Mediterranean, while another 850,000 (originating mainly in Syria, Afghanistan, Iraq and Pakistan) followed the Balkan route.

In May 2015, in view of the growing influx of immigrants into the European Union, the European Commission proposed a system of automatic distribution of applicants for refugee status or another form of protection within the EU among all member states. The relocation plan applied to persons found to be "in clear need of international protection", who were to be moved among the member states, whereas the resettlement plan referred to transfers of persons "in clear need of international protection" from third countries with the assistance of the UN High Commissioner for Refugees (Communication, 2015, p. 19). As proposed by the European Commission, the system of relocation and resettlement was to rely on the four criteria of: (1) the size of the population, reflecting the capacity to absorb a certain number of refugees; (2) total GDP, reflecting the absolute wealth of a member state and indicating possibility to absorb and integrate refugees; (3) number of asylum applications in a member state in the period of 2010-2014; (4) unemployment rate indicating the capacity to integrate refugees (ibid.). Hence, a specific relocation and resettlement formula was arrived at for each member state. Both specified the percentage of the migrants to be moved who are "in clear need of international protection", i.e. migrants eligible to receive refugee status under the Convention of 1951 or those eligible for other forms of protection available under the law. However, the presumption was for the criterion 1 and 2, as listed above, to be $40 \%$ each, and for criteria 3 and 4 to amount to $10 \%$ each. As a consequence, the highest relocation and resettlement rates, as proposed by the EC, would apply to Germany, France, Italy and Spain. ${ }^{4}$

One of the states which opposed the quota scheme proposed by the European Commission was Poland. In September 2015, faced with a growing migrant crisis and the European Commission's ever more vociferous announcement concerning the migrant quota plan for the member states, the Polish authorities issued their official position. The Prime Minister announced the government's willingness to engage in talks on possible solutions provided there would be "no pressure from people camping in the streets" (Ewa Kopacz, 2015). She stressed that the Polish government opposed an automatic topdown assignment of immigrants to member states. She committed to receive "as many refugees, but not economic migrants, as we can handle". Responding to assertions of not showing solidarity with other European Union member states, Kopacz said: "[...] First and foremost, I am the Prime Minister of Poland - my first responsibility is to my fellow citizens" (cit. after: Gawina, 2015, p. 6). This strong condemnation of the EC's proposal, as expressed in early September 2015, grew considerably weaker by September 16. On the one hand, the position was weakened in response to the castigatory tone of other EU member states on Poland's 'failure to show solidarity'. On the other, it fit well into the

${ }^{4}$ The EC proposal excluded Denmark, Ireland and the UK from the relocation system. Under Protocols 22 and 23 to the Treaty on the Functioning of the European Union, none of these states takes part in making decisions on the matters provided for in Title $\mathrm{V}$ of the Treaty regarding a common policy on immigration, visas, asylum and external border control. Ultimately, however, the European Commission included these countries in its proposed resettlement system in keeping with the reservations stated in Footnote 3 to Protocols 22 and 23. 
election campaign and was an attempt to show that the opposition was indifferent to the fates of people in need of international protection. In a parliamentary debate, the Prime Minister argued that "by turning one's back on those in need in [...] the big European family, $[\ldots]$ we are opting out of this community morally as well as mentally $[\ldots]$ We are balancing Poland's credibility in the European Union against Poles' real fears" (Rzad o, 2015). In an attempt to dispel such fears, Ewa Kopacz appeared in a television address on September 20, 2015. The Prime Minister showed that "national security and the peace of mind of Polish families are [...] a supreme value" (Wystapienie, 2015). She also stressed that there was no contradiction between caring for the security of the state and the nation and offering assistance to people seeking to save their lives and fleeing from conflict-torn areas. The central tenet of Poland's position on the migrant crisis was thus to distinguish between economic migrants and refugees. The head of the government announced that Poland's "hospitality would be extended to true refugees" while reserving the right of choosing those who would receive it (ibid.). This position stemmed from the need to respect international commitments (of the Convention relating to the Status of Refugees of 1951 and the additional protocol of 1967, to which Poland has been a party since 1991) and the desire to protect the Polish labor market and national security. As she declared solidarity with other European Union member states, Prime Minister Kopacz announced that the precondition for any joint European solutions would be to separate refugees from economic migrants, seal the external borders and have "the services complete control [...]" over the received persons. This position was presented on Poland's behalf by Minister of International Affairs at an extraordinary September meeting of the EU member state representatives.

The summit of internal affairs ministers led to the adoption of agreements on the distribution of 40,000 migrants (decision 2015/1523 of September 14th) and another 120,000 migrants (decision 2015/1601 of September 22nd) applying for refugee status or another form of protection, coming from Greece, Italy and the other member states directly affected by the migration crisis (more: Potyrała, 2015, p. 4-47). The decision of September 14 established a temporary (two-year) extraordinary mechanism for the relocation of persons from Greece and Italy to other member states. The states to which migrants in need of international protection will be transferred are to receive $€ 6,000$ per person to cover the expenses associated with the relocated people. The decision also provided for operational support for the authorities of Italy and Greece and, in particular, for help in identifying and registering persons arriving from third states (based on the Eurodac system and in cooperation with Frontex) and for preparing and implementing the return of migrants who did not apply for international protection or whose right of residence in the EU has expired. The solutions gave rise to no concerns as they followed from the consensus reached on July 20, 2015. However, opposition was raised to the decision of September 22, adopted by a majority vote, regarding the relocation of 120,000 migrants from Italy $(15,600)$, Greece $(50,400)$ and other member states $(54,000)$. The countries voting in favor of an obligatory quota scheme were France and Germany, with unexpected support from Poland and Latvia.

The Polish government's approval of the relocation scheme was criticized by the political opposition. The head of government was blamed for being unable to control an official of her administration who represented Poland at the meeting as well as for yielding 
to Germany which favored approaching relocation in keeping with the principle of European solidarity. The strongest reproach came in response to reports of an alleged consent of the Polish government to accept ca. 100,000 refugees under a permanent obligatory relocation scheme proposed by the European Commission. In an interview for wPolityce.pl, Zbigniew Ziobro noted: "Refugees deserve to be helped [...], however, any help we extend must be wise and given locally, at the scene, in countries neighboring with the conflict theater [...] What Ms. Kopacz and her associates are saying is a load of rubbish" (Ziobro, 2015). Although the reports on accepting such a large number of refugees were never confirmed, as they were only stated in non-binding announcements of the European Commission, the matter was placed on the agenda of the Polish Parliamentary Committee for the European Union. On October 8, 2015, the Committee refused to approve the idea to set up a mandatory permanent relocation scheme (Opinion 72) rejecting it as infringing on the principle of subsidiarity. In so doing, the Committee supported the official position of the government which said that: "every movement of refugees [...] should be agreed with the member states." ${ }^{\prime 5}$ The government assured that the relocation scheme agreed by the member states in September 2015 only meant that Poland would accept persons of specified identity posing no threat to state security or public order. The authorities made it clear that the consent was limited to a mere 12,000 people.

The change of government was followed by announcements of a renewed debate on the acceptable methods of resolving the migrant crisis. Representatives of Poland's new government spoke of the need to revise the agreements of September 2015. This, they argued, was necessary if Poland were to put the security of the member states and EU citizens first and only then think of ensuring the safety of any foreign nationals in need of protection. The new government also opted for having such protection extended along with humanitarian aid only in the so-called countries of first asylum, which in this case were the third countries in which the migrants arrived before they reached the European Union. For that reason, the government favored launching negotiations with such third countries regarding bilateral readmission agreements and extending financial support to those states to train their border guards, set up refugee camps and provide humanitarian assistance. The government also stressed that the EU needed to foster democratization and stabilization processes in the countries of origin. A step further was taken by Witold Waszczykowski who, shortly before he assumed his post as Minister of Foreign Affairs, proposed to return persons originating in Syria to have them fight for the liberation of their country: "The hundreds of thousands of young people who entered Europe can be made into an army" (Waszczykowski, 2015).

According to the new government, sufficient grounds for changing Poland's position on the admission of refugees were provided by the terrorist attacks in Paris in November 2015 (and conclusively determined by the Brussels attacks of March 2016). Konrad Szymański, responsible for the European Affairs within the Ministry of Foreign Affairs, pointed out that: "In view of the tragic events in Paris, Poland is left with no other political option but to withhold its approval for the relocation of refugees" (Politycy o, 2015). He stated that the admission of applicants for refugee status or any other form of protection was conditional upon the ability to ensure security. He emphasized that while

${ }^{5}$ A statement by R. Rogala, the then General Director of the Office for Foreigners within the Ministry of the Interior and Administration (cited after: Sejmowa, 2015). 
no legal ways were available to change the decisions of September 2015, Poland will execute them "in keeping with its own expectations in the field of immigration policy" (Szymański, 2015). A balanced stance was presented by Prime Minister Beata Szydło, who noted that the Paris attacks were a game changer making it necessary to go back to the negotiating table and review the continued advisability of proceeding with the measures adopted in September 2015. While reaffirming her commitment to honor the obligations assumed by the previous government, Beata Szydło made the reservation that "our top priority is the security of Polish citizens. If such commitments can be fulfilled without compromising the security of Poles, we will honor them. However, we will never agree to endanger Poles' security" (Szydło o, 2015).

This statement was officially reasserted in an exposé delivered on November 18, 2015: "[...] one must be clear on the issue of solidarity. Solidarity is about sharing the good things and standing ready to provide aid when extraordinary or dangerous events unfold. These include natural disasters, terrorist threats and the threats of war. One may not, however, stretch the meaning of solidarity to cover exportation, of sorts, of the problems which some states have created for themselves without any involvement on the part of others, which are now to bear the consequences" (Exposé, 2015). Furthermore, the Prime Minister pledged that her government would be "active and assertive."

In view of media reports coming from Germany, representatives of the two opposition parties of Kukiz'15 and KORWiN appealed to Prime Minister Beata Szydło in a letter of January 2016 to change the government's policy on immigrants and to object to "admitting Islamic immigrants into our country." In the two parties' opinion, the new government was "continuing the deplorable decisions of Ewa Kopacz [...]. If incidents similar to those seen in France and Germany are repeated in Poland, Beata Szydło will have Polish blood on her hands" (Apel, 2016). What is more, in January 2016, the Kukiz'15 movement, backed by the KORWiN party, began collecting signatures in support of a civic appeal for a referendum on refugee admission. Having noted that the government is pursuing a policy of furthering immigration that is "harmful to Poland and the Polish nation" as "we are not prepared to accept people who are culturally foreign to us," the party's leader proposed to put the following question to the nation: Are you in favor of having Poland admit refugees under the European Union relocation scheme? (Kukiz'15, 2016). As of February 2016, some 150,000 signatures of the required 500,000 were collected in support of the referendum. A counter on the dedicated Website at dzienreferendalny.pl created especially for the referendum campaign showed 193,561 votes cast as of May 16, 2016 (Stop, 2016), 95\% of which were against the admission of refugees.

The referendum initiative was criticized by the Civic Platform (PO) party and met with the skepticism of the Modern (Nowoczesna) party. Civic Platform representatives called the referendum a biased and xenophobic idea. The leaders of the Modern party agreed to support the referendum as long as it is fully financed by the Kukiz' 15 movement. The Law \& Justice (PiS) party, in its turn, came up with a draft resolution on the migration crisis expressing the Parliament's condemnation of the September 22 decision to relocate 120,000 refugees and withdrawing the previous government's support for that decision. The draft resolution stressed that the Polish Parliament was firmly opposed to any new attempts to establish a permanent mechanism for refugee admission and relocation. Interestingly, the postulate, included in the draft resolution, to "keep refugee and 
immigration policy instruments in the hands of the Polish state" (Projekt, 2016) infringes upon the principles of the functioning of the European Union. The Lisbon Treaty clearly states that both of these are community-level policies meaning that all related decisions are made in the EU and that any measures taken by the member states must be consistent with the adopted provisions. In spite of this, on February 25, 2016, the parliamentary Committee on European Union Affairs issued a favorable opinion on the draft resolution.

In the wake of the terrorist attacks in Brussels in March 2016, the government adopted a distinctly stricter position. Beata Szydło maintained firmly that: "Every state’s obligation is to protect its citizens [...]. I see no option of allowing migrants into Poland at this time" (Premier Szydto, 2016a, 2016b). This is clear evidence of the lumping together of migratory flows and terrorist threats. Minister of Internal Affairs Mariusz Błaszczak spoke in a similar vein recalling his "consistent past warnings of the existence of links between terrorist attacks and the influx of migrants into Europe" (Mariusz Btaszczak, 2016). What those statements showed was in fact a failure to comprehend the distinction between immigrants and refugees. The relocation scheme approved in September 2015 was concerned exclusively with refugees (persons in need of international protection which all EU member states are obliged to provide under international law) rather than immigrants at large.

\section{Future prospects}

The final months of 2015 and the first half of 2016 showed it was not only Poland but in fact also the majority of the European Union member states that were against responding to the migration crisis by admitting an unlimited number of foreigners and distributing them among all member states in the spirit of "solidarity". Such changes must be backed up with solutions that will help one cope with the mass influx of foreigners while attaining two pivotal objectives. One is to guarantee the individual right to seek asylum in accordance with the international law obligations imposed on all EU member states. The other is to ensure the security of the EU, the member states and EU citizens thereby making the European Union the Area of freedom, justice and security in pursuance with the treaties.

The positions of the member states, as presented in recent debates within the EU, suggest that the solidarity in the approach to asylum ${ }^{6}$ expressed in the Treaty of Lisbon will apply to constructing a common line of defense against the inflows of foreigners. Despite the European Commission's proposal of May 4, 2016 allowing the member states to be exempted from the relocation regime for a limited duration in return of a solidarity contribution of $€ 250,000$ for each person denied access to its territory, the most likely course of change will be to seal borders and have third countries neighboring on the European Union assume responsibility for persons in need of protection. Such postulates were put forward by, among others, Poland's new government. These are nevertheless unrealistic. Considering the EU's prior activities and its rather imperfect success record, the demands for political support and economic stabilization in the countries of origin as well as for a push to end the ongoing armed conflicts in such countries is doomed to

${ }^{6}$ The European Union's policies on border checks, asylum and immigration "shall be governed by the principle of solidarity and fair sharing of responsibility, including [...] financial implications, between the Member States" (The Treaty, 2007/2012, Art. 80). 
fail regardless of the declarations. The precepts may be good as the crisis can be reduced by eliminating the root causes of forced migration. In real life, however, the "more-formore" approach initiated by the events of the Arab Spring is not working. This makes it easy to foresee the future course of events: the lack of political will to admit foreign nationals is going to prompt the enactment of laws aimed at protecting the EU's area and result in extending funds and material support to third countries in line with the European principle of "the country of first asylum." None of this, however, will stop migrants from coming. One is therefore bound to witness further struggles of European and national services with growing migration pressure, and Poland's assurance of preparedness to protect its territory against a massive, uncontrolled and illegal influx of foreigners will turn out to be pure fiction.

Admittedly, the state administration is hard at work preparing the NATO summit and the World Youth Day in Kraków scheduled to take place in July 2016. These efforts are focused on strengthening the capacities to protect external borders, of whose importance the new government is well aware. On the one hand, border checks will be temporarily restored (for the period from July 2 to 31, 2016), as announced in February by Minister of Foreign Affairs W. Waszczykowski and reaffirmed on March 3, 2016 by Minister of Internal Affairs M. Błaszczak. Further 13,000 police officers, fire fighters, border guards and government security agents will be assigned to secure both events. The Polish government is likely to make an official request to Frontex for assistance in the form of border guard team(s) supported by other member states. Work is also under way to draw up a special law that will enable Poland to organize and properly secure the World Youth Day. A draft extends special temporary powers to the police (i.e. from July 1 to August 31,2016), including the right to vet volunteers for security and public order risks. It also requires Director General of the National Road and Highway Authority to designate recommended pilgrim routes and monitor road traffic volumes. Nevertheless, all of the above are only ad hoc measures taken in a mere response to upcoming events and the expected inflow into Poland of transient foreigners. Being of little help for actually resolving the migrant crisis, they fit into the growing European Union trend of countries securing their own territories against the influx of migrants. Meanwhile, Poland is postponing its fulfillment of international law obligations under which any person fleeing its own country out of a well-founded fear of persecution is to be granted the rights to apply for asylum. The current political debate largely focuses on arguments against economic immigration while overlooking the fact that the European Union is being reached by persons in need of international protection.

\section{Bibliography:}

Annual Risk Analysis 2013 (2013), FRONTEX, Warsaw.

Apel o nieprzyjmowanie imigrantów (2016), "Radio Zet", 14.01.2016, http://wiadomosci.radiozet.pl/ Wiadomosci/Kraj/Uchodzcy-w-Polsce.-Kukiz-i-KORWiN-apeluja-o-nieprzyjmowanie-imigrantow-00017207, 3.03.2016.

Communication from the Commission to the European Parliament, the Council, the European Economic and Social Committee and the Committee of the Regions. A European Agenda on Migration (2015), $\operatorname{COM(2015)~} 240$ final, 13.05.2015, Brussels. 
Convention relating to the Status of Refugees, Geneva 1951 (1991), Official Journal of the Republic of Poland, No. 119, Item 517.

Czachór Z. (2011), Prezydencja w Unii Europejskiej i jej priorytety. Analiza politologiczna, in: Priorytety prezydencji Polski w Radzie Unii Europejskiej, eds. Z. Czachór, T. Szymczyński, Poznań.

Directive 2011/95/EU of the European Parliament and of the Council of 13 December 2011 on standards for the qualification of third-country nationals or stateless persons as beneficiaries of international protection, for a uniform status for refugees or for persons eligible for subsidiary protection, and for the content of the protection granted, Official Journal of the European Union L337, 20.12.2011.

Ewa Kopacz o kryzysie imigracyjnym UE: nie godzimy się na automatyzm ws. kwot (2015), 14.09.2015, http://www.premier.gov.pl/multimedia/wideo, 3.10.2015.

Exposé premier Beaty Szydto 18.11.2015 - stenogram (2015), Kancelaria Prezesa Rady Ministrów, 18.11.2015, http://www.premier.gov.pl/expose-premier-beaty-szydlo-stenogram.html, 15.01.2016.

Gawina M. (2015), Premier: Przyjmiemy tylu uchodźców, na ilu nas stać, “Głos Koszaliński. Dziennik Pomorza", no. 216, 16.09.2015.

Jankowski D. (2011), Po „arabskiej wiośnie” - ,zima” dla europejskiej obrony, “Bezpieczeństwo Narodowe", no. 2 (18).

Jańczak J. (2011), Polish Presidency of the European Union and the Arab Spring, in: The Arab Spring, ed. B. Przybylska-Maszner, Poznań.

Kukiz'15 mówi ,stop uchodźcom” i liczy na poparcie (2016), “TVP.INFO”, 21.01.2016, http://www. tvp.info/23687744/, 3.03.2016.

Mariusz Błaszczak: Więcej policji na lotniskach (2016), "Rzeczpospolita", 22.03.2016, http://www. rp.pl/Zamachy-w-Brukseli/160329811-Mariusz-Blaszczak-Wiecej-policji-na-lotniskach.html, 23.03.2016.

Nieformalna Rada ds. Wymiaru Sprawiedliwości i Spraw Wewnętrznych (2011), http://pl2011.eu/content, 14.10.2011.

Polish Presidency in the Council of the European Union. 1st July-31 December 2011. Programme (2011), Ministry of Foreign Affairs, Warsaw.

Politycy o uchodźcach (2015), "Wprost”, 18.11.2015, http://www.wprost.pl/ar/525455, 18.01.2016.

Potyrała A. (2015), W poszukiwaniu solidarności. Unia Europejska wobec kryzysu migracyjnego 2015, "Przegląd Politologiczny", no. 4.

Premier Szydło: Nie widze możliwości, aby w tej chwili do Polski przyjechali imigranci (2016a), "Wprost", 23.03.2016, http://www.wprost.pl/ar/534434/Premier-Szydlo-Nie-widze-mozliwosci-aby-w-tej-chwili-do-Polski-przyjechali-imigranci/, 23.03.2016.

Premier Szydto po zamachach w Brukseli: Polska jest bezpieczna. Wszystkie shużby sq w pogotowiu (2016b), Kancelaria Prezesa Rady Ministrów, 22.03.2016, https:/www.premier.gov.pl/wydarzenia/aktualnosci/premier-szydlo-po-zamachach-w-brukseli-polska-jest-bezpieczna-wszystkie.html, 23.03.2016.

Projekt uchwały Sejmu Rzeczypospolitej Polskiej w sprawie polityki imigracyjnej Polski. Załacznik do Sprawozdania Komisji do spraw Unii Europejskiej o poselskich projektach uchwat w sprawie: polityki imigracyjnej państwa polskiego na forum Unii Europejskiej (druk nr 18) oraz w sprawie polityki imigracyjnej Polski (druk nr 230) (2016), Sejm Rzeczypospolitej Polskiej - VIII kadencja, druk no. 250, 25.02.2016, Warszawa.

Regulation (EU) No. 1168/2011 of the European Parliament and of the Council of 25 October 2011 amending Council Regulation (EC) No. 2007/2004 establishing a European Agency for the Management of Operational Cooperation at the External Borders of the Member States of the European Union (2011), Official Journal of the European Union L 304, 22.11.2011.

Rzad o uchodźcach podczas nadzwyczajnej debaty w Sejmie (2015), Kancelaria Prezesa Rady Ministrów, 16.09.2015, http://www.premier.gov.pl/multimedia/wideo, 3.10.2015. 
Sejmowa komisja negatywnie o propozycji stałego systemu relokacji uchodźców (2015), "Onet. wiadomości”, 8.10.2015, http://wiadomosci.onet.pl/kraj/sejmowa-komisja-negatywnie-o-propozycji-stalego-systemu-relokacji-uchodzcow/9cdpl4, 12.12.2015.

Stop ,uchodźcom” (2016), http://dzienreferendalny.pl/, 16.05.2016.

Szydło o uchodźcach: Priorytetem bezpieczeństwo (2015), "Rzeczpospolita”, 16.11.2015.

Szymański: nie ma możliwości prawnych, aby zmienić decyzjęo relokacji uchodźców (2015), 21.12.2015, http://www.parlamentarny.pl/wydarzenia/szymanski-nie-ma-mozliwosci-prawnych-abyzmienic-decyzje-o-relokacji-uchodzcow,3482.html, 3.03.2016.

The Treaty on the Functioning of the European Union, Lisbon 2007. Consolidated version, Official Journal of the European Union C 326, 26.10.2012.

Update No. 1 on the Humanitarian Situation in Libya and in the Neighbouring Countries (2011), http:// www.unhcr.org, 5.06.2015.

Update No. 26 on the Humanitarian Situation in Libya and in the Neighbouring Countries (2011), http://www.unher.org, 5.06.2015.

Waszczykowski: stwórzmy wojsko z syryjskich uchodźców. Polska armia nie pojedzie do Syrii (2015), "Wprost", 15.11.2015, http://www.wprost.pl/ar/525115, 15.01.2016.

Wystapienie premier Ewy Kopacz (2015), Kancelaria Prezesa Rady Ministrów, 20.09.2015, http://www. premier.gov.pl/multimedia/wideo, 3.10.2015.

Ziobro: Reakcja Kopacz na doniesienia 'wSieci' dot. imigrantów niewiarygodna, "wPolityce.pl”, 15.10.2015, http://wpolityce.pl/polityka/268531 (3.03.2016).

\section{Polska wobec kryzysu migracyjnego 2015-2016}

\section{Streszczenie}

Presja migracyjna, jakiej państwa członkowskie Unii Europejskiej doświadczają od początków 2015 r., skutkuje w pogłębiających się różnicach w podejściu do problemu imigrantów, dotyczących zwłaszcza tzw. systemu kwotowego uzgodnionego we wrześniu 2015 r. Niniejszy artykuł prezentuje stanowisko Polski wobec narastającego kryzysu, uzasadniające konieczność odejścia od nieograniczonego przyjmowania imigrantów, a także ukazuje podjętą przez Polskę aktywność polityczną i prawną.

Słowa kluczowe: kryzys migracyjny, uchodźcy, Unia Europejska, Polska, relokacja 
